Н.О. ТЕРЕНДА

\title{
ОСНОВНІ ТЕНДЕНЦІї ТА ПРОГНОЗНІ ОЦІНКИ ЗАГАЛЬНОЇ ТА ПЕРВИННОЇ ЗАХВОРЮВАНОСТІ НА ІШЕМІЧНУ ХВОРОБУ СЕРЦЯ В УКРАÏHI
}

\author{
ДВНЗ «Тернопільський державний медичний університет імені І.Я. Горбачевського МОЗ України», \\ м. Тернопіль, Україна
}

\begin{abstract}
Мета: вивчити динаміку показників поширеності та захворюваності населення України на ішемічну хворобу серця (IXC) у регіональному аспекті протягом 1996-2014 років та спрогнозувати їх зміни до 2025 року.

Матеріали і методи. Матеріалом дослідження слугували дані Центру медичної статистики МОЗ України про рівень первинної захворюваності та поширеності IXC серед населення України. У роботі використано епідеміологічний, демографрічний, статистичний методи дослідження.

Результати. Використовуючи метод демографрічного районування, проведено оцінку змін поширеності та захворюваності IXC в Україні та окремих ії районах протягом 1996-2014 років. Спрогнозовано тенденцію до подальшого зростання IXC, як в Україні, так і в деяких ії районах.

Висновки. Протягом останніх 19 років в Україні істотно зросла поширеність (у 2,1 разу) та захворюваність (у 1,6 разу) на IXC. Найбільше ці показники змінилися у Південному та Південно-Східному районах України. Прогнозні показники щодо поширеності та захворюваності на IXC свідчать про тенденцію до їх зростання, особливо у Південно-Східному та Південному районах.
\end{abstract}

КЛЮчОВІ СЛОВА: ішемічна хвороба серця, поширеність, первинна захворюваність, прогноз.

Низка досліджень, що проводилися починаючи з 70-х років XX століття, показує неухильне зростання поширеності серцево-судинних захворювань протягом останніх десятиліть [1;6]. Хвороби системи кровообігу (ХСК) займають перше місце в структурі загальної захворюваності та друге місце в структурі первинної захворюваності населення України.

Найбільш визначальними та соціально значущими серед ХСК за поширеністю залишаються ішемічна хвороба серця (IXC) $(33,7 \%)$ та гіпертонічна хвороба (ГХ) $(46,0 \%)$ [2;3]. Саме для даних нозологій спостерігаються найвищі темпи приросту. За період 2001-2011 рр. поширеність ГX та IXC зросли, відповідно, на 58,0\% та 49,8\% [4;5].

Мета роботи - вивчити динаміку показників поширеності та захворюваності населення України на ішемічну хворобу серця у регіональному аспекті протягом 1996-2014 років та спрогнозувати їх зміни до 2025 року.

Матеріали і методи. Матеріалом дослідження слугували дані галузевої статистичної звітності Центру медичної статистики МОЗ України про рівень первинної захворюваності та поширеності стенокардії та IXC серед населення України.

У дослідженні використано демографрічне районування [7]. Територіальною одиницею вибрано адміністративні області за такими ознаками, як

(c) Н.О. Теренда, 2016 показники відтворення населення та його віковостатевий склад, чисельність, особливості розміщення, розміри території. Виділено п'ять районів: Західний (Волинська, Закарпатська, Івано-Франківська, Львівська, Рівненська, Тернопільська та Чернівецька області), Центральний (Вінницька, Житомирська, Київська, Кіровоградська, Хмельницька і Черкаська області), Північно-Східний (Полтавська, Сумська і Чернігівська області), Південно-Східний (Дніпропетровська, Донецька, Запорізька, Луганська і Харківська області) та Південний (АР Крим, Миколаївська, Одеська і Херсонська області).

У роботі використано епідеміологічний, демографрічний методи дослідження. Статистична обробка аналізів результатів дослідження проводилася із застосуванням комп'ютерних статистичних пакетів програм Statistica 6.0 та Microsoft Excel.

Результати дослідження та їх обговорення. На першому етапі дослідження було вивчено та згруповано дані щодо поширеності та первинної захворюваності на IXC у регіональному аспекті протягом 1996-2014 років.

Загальна захворюваність на IXC в Україні зросла у 2014 р. порівняно із 1996 р. у 2,1 разу. Районні особливості зростання поширеності цієї патології полягають в істотному зростанні ії у Південному районі з 9593,2 до 24918,8 на 100 тис. нас. (у 2,6 разу) та у Південно-Східному - 3 9343,3 до 23504,8 
на 100 тис. нас. (у 2,5 разу). Також слід зазначити, що у 1996 р. показник поширеності IXC у Південному та Південно-Східному районах був нижчий за загальноукраїнські показники (відповідно 90,6\% та 88,2\%), а у 2014 р. він уже перевищував їх (відповідно 113,1\% та 106,7\%). У Центральному та
Північно-Східному районах спостерігається найменше зростання загальної захворюваності на IXC у 2,1 разу (відповідно з 12908,1 на 100 тис. нас. у 1996 р. до 26897,1 на 100 тис. нас. у 2014 р. та $з 11206,5$ на 100 тис. нас. у 1996 р. до 23480,0 на 100 тис. нас. у 2014 р.) (табл. 1).

Таблиця 1. Динаміка поширеності IXC в Україні за період 1996-2014 pp. (на 100 тис. нас.)*

\begin{tabular}{|l|c|c|c|c|c|}
\hline \multicolumn{1}{|c|}{ Територія } & 1996 р. & 2000 p. & 2005 p. & 2010 p. & 2014 p. \\
\hline Україна & 10594,2 & 14567,0 & 20751,4 & 23455,8 & 22034,1 \\
\hline Південний район & 9593,2 & 13501,4 & 19055,7 & 23041,2 & $24918,8^{\star}$ \\
\hline Центральний район & 12908,1 & 17166,7 & 22594,5 & 25850,4 & 26897,1 \\
\hline Західний район & 10189,3 & 14012,4 & 19358,7 & 22321,5 & 22612,0 \\
\hline Південно-Східний район & 9343,3 & 13353,4 & 20711,5 & 23301,5 & $23504,8^{\star}$ \\
\hline Північно-Східний район & 11206,5 & 14665,6 & 20570,7 & 22402,4 & 23480,0 \\
\hline
\end{tabular}

Примітка. Статистичні дані подані без урахування даних із Автономної Республіки Крим, Донецької і Луганської областей через відсутність моніторингових даних з тимчасово окупованих територій.

При детальнішому аналізі можна відмітити найвищі рівні загальної захворюваності на IXC в Україні за період 2012-2013 рр., які співвідносилися 3 усіма регіонами.

Серед областей можна відмітити найбільше зростання поширеності IXC у Запорізькій - 3 5439,1 на 100 тис. нас. до 20416,7 на 100 тис. нас. (3,8 разу), Херсонській - з 6940,9 на 100 тис. нас. до 23775,4 на 100 тис. нас. (3,4 разу) та Дніпропетровській - $з$ 8601,84 на 100 тис. нас. до 26 425,00 на 100 тис. нас. (3,1 разу) областях. Найменші темпи збільшення загальної захворюваності на IXC в Україні за досліджуваний період спостерігалися у Сумській - 3 12453,4 на 100 тис. нас. до 21298,3 на 100 тис. нас. (1,7 разу) та Чернівецькій - 3 14150,2 на 100 тис. нас. до 25965,4 на 100 тис. нас. (1,8 разу) областях.

Подібні тенденції спостерігалися і при вивченні динаміки первинної захворюваності на IXC в Україні протягом 1996-2014 років.
Так, первинна захворюваність на IXC збільшилася в Україні в 2014 р. у 1,6 разу порівняно із 1996 роком. Найбільше вона зросла у Південному - 3 794,6 на 100 тис. нас. до 1912,1 на 100 тис. нас. (2,4 разу) та Південно-Східному - 3 702,9 на 100 тис. нас. до 1437,3 на 100 тис. нас. (2,0 разу) районах. Найменше змінилися показники первинної захворюваності у Північно-Східному - 3 997,3 на 100 тис. нас. до 1357,7 на 100 тис. нас. (1,4 разу), Західному - 31020,5 на 100 тис. нас. до 1517,0 на 100 тис. нас. (1,5 разу) та Центральному 3 951,7 на 100 тис. нас. до 1428,4 на 100 тис. нас. (1,5 разу) районах. При цьому первинна захворюваність у Південному та Південно-Східному районі у 1996 р. була нижчою порівняно із загальноукраїнськими даними (відповідно на 93,2\% та 82,4\%), а у 2014 р. уже перевищувала їх (відповідно $138,7 \%$ та 104,3\%) (табл. 2).

При оцінюванні динаміки первинної захворюваності на IXC за областями України за досліджува-

Таблиця 2. Динаміка захворюваності на IXC в Україні за період 1996-2014 рр. (на 100 тис. нас.)*

\begin{tabular}{|l|c|c|c|c|c|}
\hline \multicolumn{1}{|c|}{ Територія } & 1996 р. & 2000 p. & 2005 p. & 2010 p. & 2014 p. \\
\hline Україна & 852,6 & 1513,3 & 1697,5 & 1708,4 & 1378,6 \\
\hline Південний район & 794,6 & 1272,8 & 1590,9 & 1952,3 & $1912,1^{*}$ \\
\hline Центральний район & 951,7 & 1659,6 & 1572,6 & 1590,7 & 1428,4 \\
\hline Західний район & 1020,5 & 1558,5 & 1881,1 & 1774,2 & 1517,0 \\
\hline Південно-Східний район & 702,9 & 1524,2 & 1650,6 & 1657,8 & $1437,3^{\star}$ \\
\hline Північно-Східний район & 997,3 & 1617,9 & 1506,0 & 1421,7 & 1357,7 \\
\hline
\end{tabular}

Примітка. Статистичні дані подані без урахування даних із Автономної Республіки Крим, Донецької і Луганської областей через відсутність моніторингових даних з тимчасово окупованих територій.

ний період виявлено істотне зростання патології у Миколаївській - 3 793,2 на 100 тис. нас. до 2567,8 на 100 тис. нас. (3,2 разу), Дніпропетровській - 3
685,4 на 100 тис. нас. до 1718,4 на 100 тис. нас. (2,4 разу) областях та Автономній Республіці Крим - 3 554,2 на 100 тис. нас. до 1 551,5 на 100 тис. 
нас. (2,8 разу - дані за 2013 р.). Найменше зросла первинна захворюваність протягом 1996-2014 рр. у Закарпатській - 31680,8 на 100 тис. нас. до 1748,00 на 100 тис. нас. (104,0\%) та Чернівецькій 3 1621,2 на 100 тис. нас. до 1705,3 на 100 тис. нас. (105,2\%) областях і навіть зменшилася у Київській області - $з$ 1537,2на 100 тис. нас. до 1381,3 на 100 тис. нас. (89,9\%).

Другим етапом дослідження стало прогнозування динаміки поширеності та захворюваності на IXC в Україні та по районах до 2025 року.

Прогнозні дані свідчать про тенденцію до зростання поширеності IXC в Україні. Так, загальноукраїнські показники поширеності прогнозовано зростуть 3 22034,1 на 100 тис. нас. у 2014 р. до 34680,5 на 100 тис. нас. у 2025 р. (+63,5\%). У інших районах, де спостерігається найістотніше зростання загальної захворюваності на IXC за досліджуваний період, прогнозуються такі зміни. У Південному районі показник зміниться $з 23$ 916,8 на 100 тис. нас. до 36076,4 на 100 тис. нас. $(+49,3 \%)$, у Південно-Східному районі - $з$ 23504,8 на 100 тис. нас. до 36475,1 на 100 тис. нас. $(+64,4 \%)$. Також прогнозовано істотно зросте захворюваність у Центральному районі - 326 045,5 на 100 тис. нас. до 38180,8 на 100 тис. нас. (+68,2\%). В даному районі вона була вищою порівняно із загальноукраїнськими показниками протягом усього періоду спостереження (рис. 1).

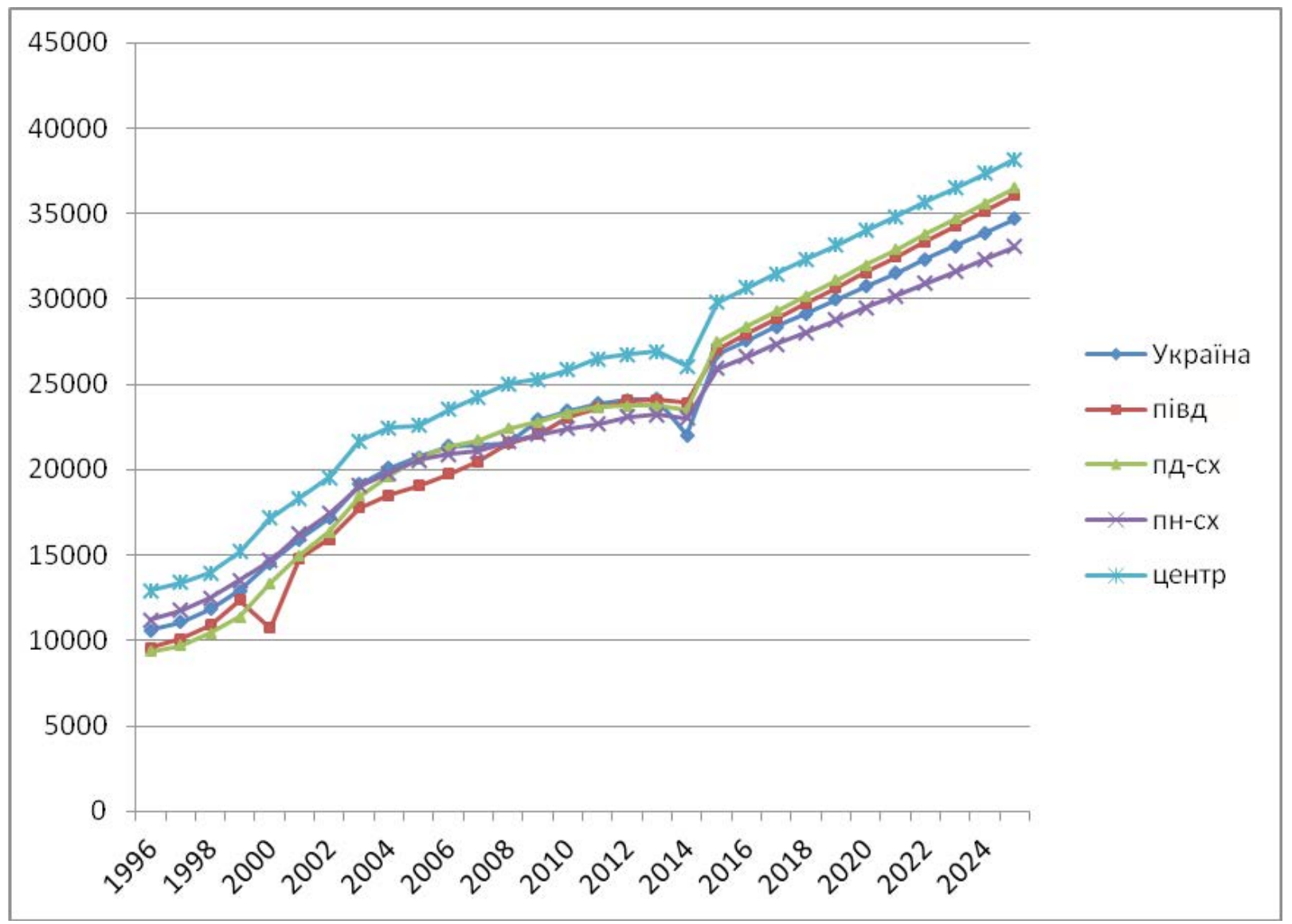

PUс. 1. Прогноз поширеності IXC в Україні та районах до 2025 року (на 100 тис. нас.)

Подібна тенденція спостерігається і при прогнозуванні первинної захворюваності на IXC. Так, загальноукраїнські показники зростуть із 1378,6 на 100 тис. нас. у 2014 р. до 2177,6 на 100 тис. нас. у 2025 р. (+61,1\%). Рівень первинної захворюваності прогнозовано найбільше зросте у Північно-Східному - $з$ 1357,7 на 100 тис. нас. до 1619,0 на 100 тис. нас. (+83,9\%), у ПівденноСхідному - 3 1437,3 на 100 тис. нас. до 2278,2 на 100 тис. нас. $(+63,1 \%)$ та Південному - 3 1912,1 на 100 тис. нас. до 2819,7 на 100 тис. нас. (+67,8\%) районах (рис. 2).

\section{Висновки}

1. Поширеність IXC в Україні зросла у 2014 р. порівняно із 1996 р. у 2,1 разу. Найістотніше вона збільшилася у Південному (у 2,6 разу) та Південно-Східному (у 2,5 разу) районах України.

2. Захворюваність на IXC збільшилася в Україні у 2014 р. у 1,6 разу порівняно із 1996 роком. Найбільше вона зросла у Південному (у 2,4 разу) та Південно-Східному (у 2,0 разу) районах.

3. Прогнозовано поширеність IXC в Україні до 2025 р. зросте на 63,5\%. Найбільше зростання очікується у Центральному (+68,2\%), Південно- 


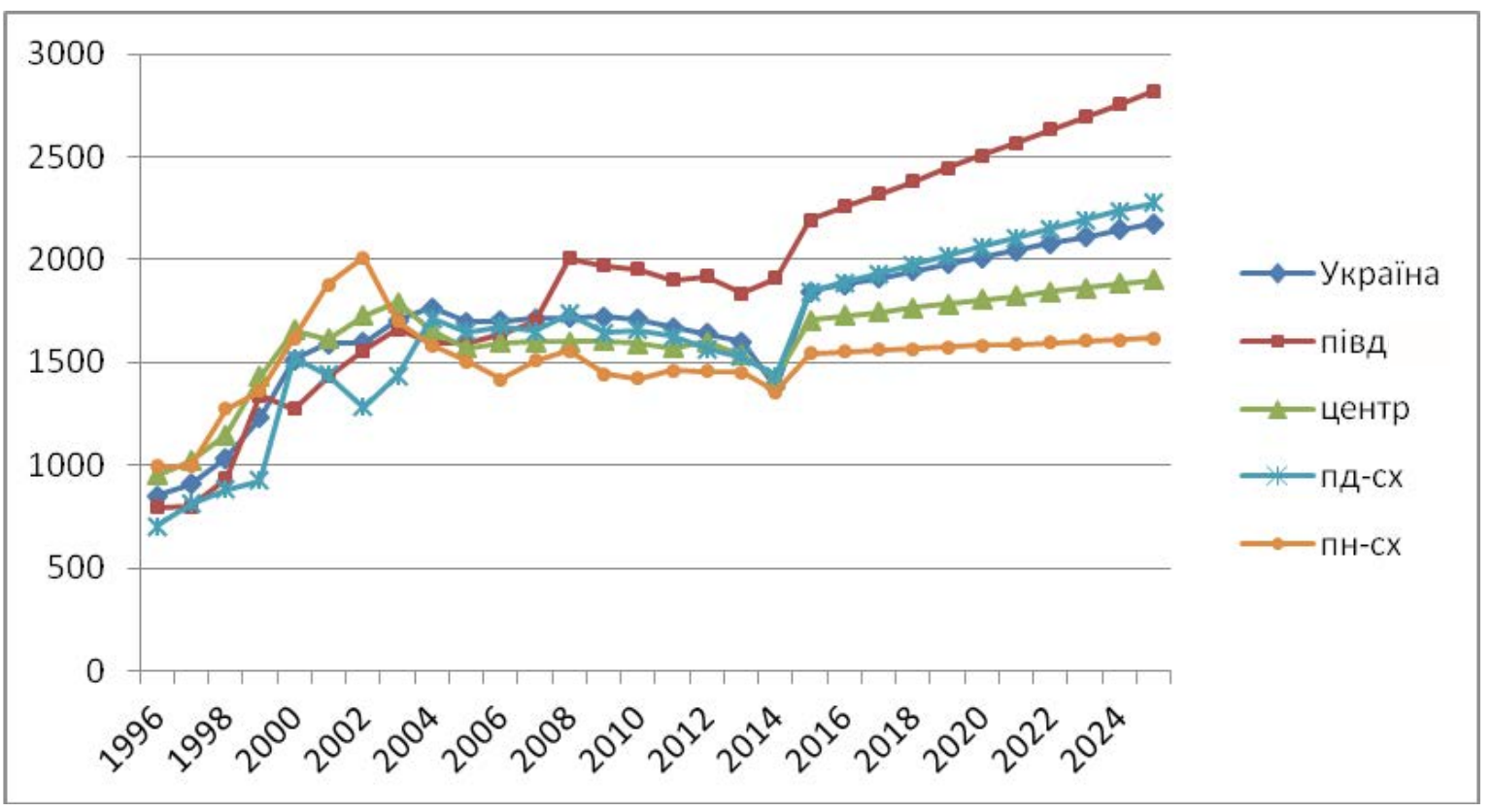

Puc. 2. Прогноз захворюваності IXC в Україні та районах до 2025 року (на 100 тис. нас.)

Східному $(+64,4 \%)$ та Південному $(+49,3 \%)$ районах.

4. Первинна захворюваність на IXC прогнозовано збільшиться в Україні на 61,1\%, у ПівнічноСхідному районі - на +83,9\%, у Південно-Східному - на $+63,1 \%$, у Південному - на $+67,8 \%$.
Перспективи подальших досліджень полягають у вивченні динаміки захворюваності та поширеності основних захворювань серцево-судинної системи в Україні та їх прогнозі.

\section{Список літератури}

1. Горбась I. М. Епідеміологічна ситуація щодо серцево-судинних захворювань в Україні: 30-річне моніторування / І. М. Горбась // Практична ангіологія. - 2010. - № 9-10 (38-39). - С. 4-10.

2. Дячук Д. Д. Щодо захворюваності дорослого населення України на неінфекційні хвороби / Д. Д. Дячук // Вісник соц. гігієни та орг. охорони здоров'я України. - 2011. - № 1. - С. 19-23.

3. Клименко В. І. Хвороби системи кровообігу як медико-соціальна державна проблема / В. І. Клименко // Вісник соц. гігієни та орг. охорони здоров'я України. - 2007. - № 4. - С. 17-21.

4. Рингач Н. О. Серцево-судинні захворювання в Україні: статистичний аналіз сучасної епідеміологічної ситуації [Електронний ресурс] / Н. О. Рингач, О. О. Чернобривенко. - Режим доступу : http://medstrana.com/articles/1639/. Назва з екрану.

5. Слабкий Г. О. Визначення проблемних областей України при прогнозуванні захворюваності працездатного населення / Г. О. Слабкий, Д. Д. Айстраханов, Г. В. Курчатов // Вісник соц. гігієни та орг. охорони здоров'я України. 2009. - № 1. - С. 28-33.

6. Теренда Н. О. Прогностична оцінка захворюваності та поширеності хвороб системи кровообігу / Н. О. Теренда // Вісник соц. гігієни та орг. охорони здоров'я України. - 2014. - № 4 (62). - С. 31-35.

7. Ященко Ю. Б. Динаміка захворюваності та смертності внаслідок хвороб системи кровообігу в Україні у регіональному аспекті / Ю. Б. Ященко, Н. Ю. Кондратюк // Вісник соц. гігієни та орг. охорони здоров'я України. 2012. - № 3. - C. 25-29.

\section{ОСНОВНЫЕ ТЕНДЕНЦИИ И ПРОГНОЗНЫЕ ОЦЕНКИ ОБЩЕЙ И ПЕРВИЧНОЙ ЗАБОЛЕВАЕМОСТИ ИШЕМИЧЕСКОЙ БОЛЕЗНЬЮ СЕРДЦА В УКРАИНЕ}

Н.А. Теренда

ГВУЗ «Тернопольский государственный медицинский университет имени И.Я. Горбачевского МЗ Украины»,

г. Тернополь, Украина

Цель: изучить динамику показателей распространенности и заболеваемости населения Украины ишемической болезнью сердца (ИБС) в региональном аспекте на протяжении 1996-2014 годов и спрогнозировать их изменения до 2025 года.

Материалы и методы. Материалом исследования послужили данные Центра медицинской статистики Минздрава Украины об уровне первичной заболеваемости и распространенности ИБС среди 
населения Украины. В работе использованы эпидемиологический, демографический, статистический методы исследования.

Результаты. Используя метод демографического районирования, проведена оценка изменений распространенности и заболеваемости ИБС в Украине и отдельных ее районах в течение 1996-2014 годов. Спрогнозировано тенденцию дальнейшего роста ИБС как в Украине, так и в определенных ее районах.

Выводы. В течение последних 19 лет в Украине существенно возросла распространенность (в 2,1 раза) и заболеваемость (в 1,6 раза) ИБС. Более всего эти показатели изменились в Южном и Юго-Восточном районах Украины. Прогнозные показатели по распространенности и заболеваемости ИБС свидетельствуют о тенденции их увеличения, особенно в Юго-Восточном и Южном районах Украины.

КЛЮЧЕВЫЕ СЛОВА: ишемическая болезнь сердца, распространенность, первичная заболеваемость, прогноз.

\section{TRENDS AND FORECAST ESTIMATIONS GENERAL AND PRIMARY MORBIDITY ISCHEMIC HEART DISEASE UKRAINE \\ N.O. Terenda \\ SHEI «Ternopil State Medical University named after I. Gorbachevskyi Ministry of Health of Ukraine», Ternopil, Ukraine}

Purpose: to study dynamics of indicators of prevalence and morbidity for coronary heart disease (CHD) of the population of Ukraine in regional aspect during 1996-2014 and to forecast their changes in 2025.

Materials and methods. As research materials were used the data of Center of Health Statistics of the Ministry of Health of Ukraine on the level of primary incidence and prevalence of CHD in the population of Ukraine. In our research, epidemiological, demographic, statistical methods of research are used.

Results. Using the method of demographic regions, we estimate changes in prevalence and incidence of CHD in Ukraine and its separate regions for 1996-2014. tendency of further growth in CHD is predicted both for Ukraine on the whole and for some districts.

Conclusions. Over the last 19 years in Ukraine prevalence and morbidity of CHD has significantly increased -2.1 and 1.6 times respectively. More of these indicators have changed in Southern and Southeastern regions of Ukraine. Projected figures on prevalence and incidence of CHD indicate a tendency of their growth, especially in Southeastern and Southern regions.

KEY WORDS: coronary heart disease, prevalence, primary incidence, forecast.

Рукопис надійшов до редакції: 20.09.2016

\section{Відомості про автора:}

Теренда Наталія Олександрівна - к.мед.н., доцент кафедри соціальної медицини, організації та економіки охорони здоров'я з медичною статистикою ДВНЗ «Тернопільський державний медичний університет імені І.Я. Горбачевського МОЗ України»; тел.: +38(0352)-52-72-33. 